\title{
The Wreck of the Deutschland: A Poem of Adoration and Trepidation
}

\author{
Helen Unius Backiavathy, Corneli Agnes Rosabella
}

\begin{abstract}
The Wreck of the Deutschland is a long, partly narrative work of Gerard Manley Hopkins depicting the intensity of the poet's pent-up feeling about the shipwreck, the cry, the prayers of the five German nuns who were sent on exile. The Victorian poet portrays two central themes on God revealing Himself as an omnipotent to mankind and that man's response to God through many alliterative phrases in the poem. The wreck served as an impetus to the poet to give shape to the religious thoughts that had been fermenting in his brain and the first part of the poem is a profound religious meditation upon God and the poet's personal relationship with God. The second part chronicles the suffering, death and resurrection and is as such, an ethic on martyrdom where the dual nature of God is revealed. He not only offers salvation, but also doles judgement. Thus the poem characterizes the unity which sketches the poet's concern for the sensuous beauty of nature and his ardent belief in God and is composed for a man to praise, magnify, exalt, adore and serve God with awe, trepidation and reverence.
\end{abstract}

Key words: The Wreck of the Deutschland, Gerard Manley Hopkins, adoration, trepidation, dual nature

\section{INTRODUCTION}

Gerard Manley Hopkins, one of the influential poets of the Victorian Age was singular from his contemporaries. Though Hopkins was a poet of the Victorian Age, his works depict a complete shift from its tradition as he employed metre and language freely and unconventionally and paved route for modern poetry. The Victorian ideals are exemplified in Hopkins's life and accomplishments. It is evident from most of his poems that he had a profound love for nature.

The poetry of Hopkins might be called a passionate science. Like other poets and painters of his era, he delighted in the observation and grasping of nature. The poems revealed the greatest delicacy, strength and intelligence he possessed in making it the inseparable vehicle for the passionate praises of his belief. His poems seemed strangely new and curiously in keeping with the mood and style of the new century. He brought in a revolution and it was explicit as there was an exuberant intelligence in rhythm and language. He had a great sensitivity to nature, especially trees, water, and clouds, and always saw God as very much present and part of nature.

The Wreck of the Deutschland was rather long, partly declamatory and partly narrative showing in every word and lines the intensity of the poet's pent-up feeling. This ship wreck was not just a wreck but it created a deep impression on him. In the wreck, he saw two central and balancing movements which continually occupied his thoughts. They are, first, God moving towards man or showing Himself to

Revised Manuscript Received on 14 August, 2019.

Helen UniusBackiavathy, Assistant Professor, Department of English, Karunya Institute of Technology and Sciences, Coimbatore, Tamil Nadu, India. (Email: heleneuniceravi@gmail.com)

Corneli Agnes Rosabella, Assistant Professor, Department of English, Karunya Institute of Technology and Sciences, India. man and the second, man's response to God. The poem was a new assertion of God's place in the world, and Hopkins parallels them with an affirmation of acceptance. The poet begins the poem with a meditation on God's infinite power and omnipotence. He perceives the majesty and terror, the beauty and love of God. The poet concludes the first part with a prayer to God to sweep away, through His strength and even more through His sweetness, man's rebellious denial of Him. The second part of the poem is a picturesque description of the nature and its beauty. The nun's cry was a result of a desire for relief from sheer toil and monotony of daily life. The poet pays his homage to God for His supreme power, majesty and inscrutable wisdom.

The Wreck of the Deutschland analyses the delight in natural phenomena so exactly caught in language to praise, show reverence, adoration and service to God. The poem depicts the poetic force and the vital awareness of the objective beauty of the world. Hopkins believed that the poet is by nature a dreamer, a sensualist, in other words an aesthete, and that he should raise himself to greatness through liberty and religion.

Nature was always a fascination to Hopkins not only because of its sensuous appeal, its grandeur, its splendours and wonders, its superb beauty, its infinite variety, its tremendous power and force, but also because it mirrors God and reveals Him in all its manifestations. Hopkins' vision of God is integral to his vision of nature. He simply cannot help seeing God or Christ in nature. No sooner does he set his eyes upon a scene of nature than he finds himself face to face with God, benign or wrathful as the case may be, because he sees both these aspects of God.

The poem is characterized by a unity which includes the artist who is concerned with the beauty of nature and the artist's ardent belief in Christ. The poem reveals the presence of a God of infinite goodness and beauty in nature and it is full of excited joy at the meaning and reality given to nature by this religious concept. To Hopkins, God and Christ is seen in all aspects of nature and thus this poem is an adoration to God's glory.

Hopkins was profoundly affected by the dramatic aftermath when in December 1875, five Franciscan nuns, exiled from their Westphalian convent, lost their lives in a shipwreck near the mouth of the Thames. Bismarck, the first Chancellor of German Empire, with the help of Count Falck, passed several laws to curtail the Catholic Church in Germany and as a result convents were closed and the nuns exiled. The nuns, who were the devoted servants of God, were first subjected to humiliation of exile and then to the harrowing experience of the storm that ended in their

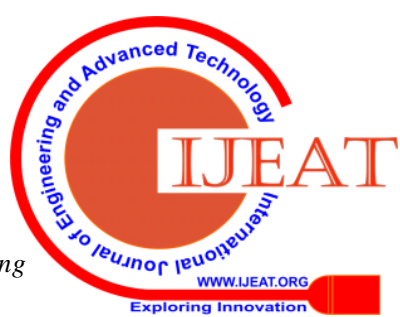


drowning. The opening stanza celebrates God as the creator and master and hence, there is a feeling of adoration mingled with feelings of awe and trepidation. The second part of the poem is the recreated expression of the voyage by the poet himself. The vessel set out from Bremen to New York on Saturday, anchoring overnight near Bremerhaven at the mouth of the Weser was thrust into the North Sea and headed west because it was urged by the heavy winds and squalls of snow. The ship was a solid British-built iron ship and the German company to which the ship belonged had run a regular Trans Atlantic service to New York since 1857 without losing a single life. The crew on board was overconfident of their mastery and they neglected the tidal currents region of deadly sandbanks off the mouth of the Thames where many ships were destroyed. The ship fought for her life, enduring the pounding of the seas without breaking up. The ship was stranded for two nights and the rescue operations could not reach the spot. The children and women who remained in a safer place were also in peril and the nuns with some other women were in their prayers. When a great wave swept overboard one woman hanged herself and another man committed suicide by cutting his vein. The tallest of five nuns, thrusting her head through the skylight, could be heard above the storm calling God to come quickly and save them.

The wreck and causalities involved moved Hopkins' heart and this disaster is not the subject of the poem. This served only as an impetus to the poet to give shape to the religious thoughts that had been fermenting in his brain and the first part of the poem is a profound religious meditation upon God and the poet's personal relationship with God. The poem reflects God as the giver of breath and bread and the Lord of the living and the dead. The glory of God seen in nature has to be proclaimed by human beings as God combines mercy with mastery. He is wrathful but loving,

Thou art lightning and love, I found it a winter and warm' (St. 8)

The poet gives a striking evidence of his descriptive gift and shows himself as a master of word-painting. His pictures of the snowstorm and the foam-crested sea-waves are unforgettable.

And the sea flint-flake, black-backed in the regular blow, 13)

Wiry and white-fiery and whirlwind-swivelled snow (St.

The use of alliterative phrases such as flint-flake, blackbacked, whirlwind-swivelled is noteworthy. In the following lines there is a contrast between the fury of the storm and the benevolence of God's light:

Surf, snow, river and earth

Gnashed: but thou art above, thou Orion of light...

Storm flakes were scroll-leaved flowers, lily showers- (St. 21)

The picture of the nun braving the rage of the elements is vivid through

And the inboard seas run swirling and hauling:

The rash smart sloggering brine

Blinds her; but she that weather sees one thing, one; (St. 19)

Apart from these awe-inspiring pictures of the violence of nature there are some exquisite pictures of nature's beauty and loveliness. In addition to "the stars and starlight", and the "dappled-with-damson west", there are also pictures of the "dawn-dugged ground-hugged grey" vanishing, "the jayblue heavens appearing of pied and peeled May", "bluebeating and hoary-glow height", and "night with belled fire and the moth-soft Milky Way". The scenes of nature on earth in Hopkins's depiction present more enchantment than the beauty of heaven. The originality and felicity in the use of language is also noteworthy that nature is to Hopkins a revelation of God in a sense more profound than it was to the Romantics. In sheer rapture the poet kisses his hand to the loveliness of stars, to the setting sun, finding glory in thunder, and greeting his God in all the aspects of nature. Unlike Wordsworth, Hopkins sees God in the terrifying aspects of nature not less than in the beautiful ones. The terrifying aspects such as "the snowstorm and the wild sea", reveal to Hopkins the might and power of God and not God's cruelty or hostility to mankind.

A German nun, one of the five exiled by persecution, had stood out into the wind and breaking waves to cry, "O Christ, Christ, come quickly". To Hopkins they were inspiring yet enigmatic words and he could feel her faith but could not give a precise account of her motives in uttering such powerful words. Through his own experience he worked through the possible meanings of her cry and Hopkins doubted if it could be the desire of a would-be martyr to re-enact her Master's passion, or simply a yearning for the crown of heavenly peace. He realized that it was something less obvious but in the end even more significant, nothing less than an acknowledgement of Christ's living presence in the scene, an awareness that could only have been achieved by someone who is able to transcend one own self in the manner of Christ himself and to utter as in:

Word, that heard and kept thee and uttered thee outright. (St. 30)

In a sense the nun conceives Christ within herself, as the Virgin Mary did, at the same time, she acknowledges Him as a living presence beyond herself, eternally incarnated in the universe. The imagery of these stanzas is complex as Hopkins strives to articulate the ineffable, but the experience itself is powerfully conveyed and the conclusions drawn from it are firm and unambiguous. Without Christ, the scene would have been a meaningless horror, an unshakeable shock night but His presence gave shape and significance to the event.

The first eleven stanzas of the poem are an astonishingly well-sustained adoration in lyrical expression of Hopkins's own knowledge and love of God. In the last lines of the first stanza, there is an unmistakable description of a mystical experience:

........ and dost thou touch me afresh?

Over again I feel thy finger and find thee. (St. 1)

This "touch" of God, expressed in entirely concrete terms, is in a language familiar to readers of mystical literature throughout the ages. The poem continues with an account of the "terror" and "stress" of the poet when confronted by 
God and the terror is that of awe, not of craven fear. But the poet moves away from this sense of almost unbearable awe to the comfort and simplicity of the Holy Eucharist:

I whirled out wings that spell

And fled with a fling of the heart to the heart of the Host. (St. 3)

The soul "flings" itself into the mercy of Christ. Hopkins then acknowledges both His weakness and strength. He is the "soft sift in an hourglass" and also "steady as a water in a well". The water can easily be stirred but is controlled and kept in balance by grace. The fifth stanza is the beginning of Hopkins's hymn to creation:

I kiss my hand

To the stars, lovely-asunder

Starlight, wafting him out of it; and

God is seen in this part of the poem as both immanent and transcendent, and Hopkins expresses the belief that God can be found in natural things. His is the way of the affirmation of images as in:

Since, tho' he is under the world's splendour and wonder,

His mystery must be instressed, stressed;

For I greet him the days I meet him, and bless when I understand. (St. 5)

The poet then goes on to say that this love is not received from some lofty being far removed from mankind but that it begins and dates from his going in Galilee, that is, from the date of the Incarnation, or the birth of Christ. This love, which 'rides time like riding a river', demands suffering and submission, both from man and from Christ. It should, however, be noted that Hopkins is not denying valid mystical experience to all those visionaries who lived before definitely:

Though felt before, though in high flood yet (St.7)

From this exalted presentation of the Incarnation, Hopkins moves to a celebration of the Blessed Trinity and speaks of the abstract idea of God in concrete terms:

Be adored among men, God three-numbered form (St. 9)

Further, he depicts the struggle to find words which will embody the experience of union with Christ. He portrays the experience at its very moment of accomplishment and consummation:

But how shall I... make me room there.... there then! the Master (St. 28)

Additionally, God is shown not simply as "master of the tides" and "of the year's fall" but also as "ground of being and granite of it" immanent and transcendent, "throned behind Death" as depicted in:

Of the Yore-flood, of the year's fall; ...

Ground of being, and granite of it; past all

Grasp God, throned behind

Death ...... (St. 32)

God as revealed in this poem is a being who can be refused, wrestled with, or surrendered to. There is nothing passive about man's approach to Him. He is terrible but merciful too and he is to be found, not simply through man's sorrow for sin, but also through man's immense desire for beauty:

With a mercy that outrides
Glow, glory in thunder. (St. 5) the coming of Christ but also on the contrary he states

\section{3)}

The well of water... fetched in the storm of his strides (St

God's presence in nature is explicitly and clearly described in the poem in the lines where Hopkins kisses his hand to the stars and star light and to the dappled with damson West, seeing God "under the world's splendour and wonder", and saying that God's mystery must be perceived and proclaimed. God's all pervasive presence is also implied through the stanza as "master of the tides", "of the yoreflood", "of the year's fall", and Hopkins could see Christ in the snow storm through the nun's eyes:

....... there then! the Master,

the only one, Christ, King, Head: (St. 28)

The snowstorm expresses the wrathful aspect of God and this aspect is benevolent in the end. In short, this poem shows a rich interpretation of changing natural phenomena and permanent spiritual realities. Hopkins was truly a poet of nature and he has sung of God's beauty as revealed in creatures. He was deeply aware of this divine communication in the multitudinous variety of visible creation. He considered his appreciation of nature as the channel of divine communication and also as a tool to sharpen his interest in the particular and individualized aspects of nature through which that communication is realized.

The entire work grapples with this problem of suffering and misfortune and throws it into proper supernatural perspective that God is the key of the world's "splendor and wonder"; He is wafted out of the stars, and "the dappledwith-damson West"; but "his mystery of suffering could be perceived precisely because it is not easy to see God's stress there:

\section{I kiss my hand}

To the stars, lovely-asunder

Starlight, wafting his out of it; and

Glow, glory in thunder;

Kiss my hand to the dappled-with-damson west;

Since, tho' he is under the world's splendour and wonder,

His mystery must be instressed, stressed;

For I greet him the days I meet him, and bless when I understand. (St. 5)

Men often fail to recognize the hand of God in their storms of life. The greatest grace experienced by men is not in the blissful manifestations of God, but is in these very strokes and storms that bring men to his knees. When nothing else will move or melt man to repentance or love, suffering will often succeed:

Not out of his bliss

Springs the stress felt

Nor first from heaven (and few know this)

Swings the stroke dealt-

Stroke and a stress that stars and storms deliver,

That guilt is hushed by, hearts are flushed by and meltBut it rides time like riding a river

(And here the faithful waver, the faithless fable and miss). (St. 6) 
Suffering is as inescapable as life itself. When confronted with it, even "the faithful waver"; but "the faithless fable and miss" (St. 6, Ln. 8). The only source of stability in the face of suffering is at the feet of the "hero of Calvary" (St. 8, Ln. 7). By His suffering Christ gave suffering a new value and meaning. He elevated it to the dignity of redemptive and reparative sacrifice. From Calvary every other sacrifice derives its meaning and value. Like the sufferings of the five nuns of the Deutschland, the suffering of all men can be paralleled with the sufferings of Christ, and taken on some of their reparative and redemptive value as seen in:

Five! The finding and sake

And cipher of suffering Christ.

Mark, the mark is of man's make

And the word of it Sacrificed.

But he scores it in scarlet himself on his own bespoken,

Before-time-taken, dearest prized and priced. (St. 22)

Not only does this explain suffering, but also elevates and enriches it. Where there is great love of God, and suffering is seen to be His will, it will be accepted wholeheartedly and generously.

\section{DISCUSSION \& RESULTS}

The first section of the poem is personal chronicle of Hopkins's attainment of his religion where God is addressed as "Thou mastering me" (St. 1), "Thy terror" (St. 2), "The frown of his face" (St. 3). Hopkins's submission seems to be complete and he feels that he is malleable in the hands of God. The presence of God is felt throughout the poem and it is the nature of presence that Hopkins is attempting to establish. It is again an attempt at a tenuous balance of the aesthetic and ascetic before he launches an ethical appraisal on the events around the Deutschland. The second section chronicles suffering, death and resurrection and is as such, an ethic on martyrdom and also defines the dual nature of God. He not only offers salvation, but also doles judgement. Hopkins has unraveled this attribute about God in the poem. The treatment of nature and its influence is vividly and explicitly dealt in aesthetic terms. Nature is capable of both growth and decay. He has crafted an aesthetic along with the ascetic in which God or Christ is immanent in all of nature and its creations.

The poem is characterized by a unity which includes the artist who is concerned with the sensuous beauty of nature and the poet who is an ardent believer in God. It reveals the presence of a God of infinite goodness and beauty in nature and they are full of excited joy at the meaning and reality given to nature by this religious concept. It is this that chiefly distinguishes Hopkins treatment of nature from that of the Romantics. Wordsworth and Shelley perceived a divine spirit in all objects of nature but Hopkins almost actually saw God and Christ in all nature. Thus Hopkins's nature poetry can be read on two different levels, one for its delight in natural phenomena so exactly caught in language structures of superb energy, and the other for its religious appeal. Thus this poem is created for a man to praise, magnify, exalt, adore and serve God with awe and reverence.

\section{REFERENCES}

1. Hopkins, Gerard Manley, William Henry GARDNER, and Norman Hugh MACKENZIE. The Poems of Gerard Manley Hopkins. Edited... by WH Gardner and NH MacKenzie. Oxford University Press, 1967.

2. Bergonzi, Bernard, and Isobel Armstrong. "The Major Victorian Poets: Reconsiderations." (1969).

3. Attridge, Derek, and Attridge Derek. Poetic rhythm: an introduction. Cambridge University Press, 1995.

4. Barber, Charles Laurence. Poetry in English: an introduction. Macmillan, 1983.

5. Devasahayam, Amirtham. Understanding Hopkins: The New Spring Poetry. Karnataka Viceprovince of the Society of Jesus at St. Joseph's College, 1981.

6. Edwards, Michael. Poetry and possibility. Springer, 1988.

7. Griffiths, Eric. The Printed Voice of Victorian Poetry. Oxford University Press, 2018.

8. Hopkins, G. M. (1967). The Sermons and Devotional Writings of Gerard Manley Hopkins.

9. Hunter, Jim. Gerard Manley Hopkins. Evans Bros., 1966.

10. Attridge, Derek. The rhythms of English poetry. Routledge, 2014.

11. Kanadey, V. R. Nature in modern English poetry Sterling Publishers, 1985.

12. Kelly, Bernard William. The Mind \& Poetry of Gerard Manley Hopkins, SJ. No. 38. Ardent Media, 1935.

13. Lowell, Robert. "Hopkins's Sanctity." the Kenyon Critics, Gerard Manley Hopkins: A Critical Symposium (New York: New Directions, 1945). 1987.

14. MacKenzie, Norman H., and Catherine Phillips. A reader's guide to Gerard Manley Hopkins. Thames and Hudson, 1981.

15. Milroy, James RD. The Language of Gerard Manley Hopkins. Diss. Queen's University Belfast, 1977.

16. Cunningham, Valentine, ed. The Victorians: An Anthology of Poetry and Poetics. Wiley-Blackwell, 2000.

17. Russell, Jeremy Francis John. A critical commentary on Gerard Manley Hopkins's poems. Macmillan _, 1971.

18. Stephen, Martin. English literature: A student guide. Routledge, 2013.

19. Storey, Graham. A preface to Hopkins. Routledge, 2014.

20. Hopkins, Gerard Manley. Look up at the skies!: Poems and prose chosen and introd. by Rex Warner. Ill. by Yvonne Skargon. Bodley Head, 1972.

\section{WEBSITES}

1. www.gerardmanleyhopkins.org

2. www.jottings.ca/john/hopkins 3. html

3. www.victorianeweb.org/authors/hopkins/hopkins12.html 